\title{
Effect of bypass fat on growth and body condition score of male Beetal goats during summer
}

\author{
I. Mohsin ${ }^{1}$, M.Q. Shahid ${ }^{1}$, M.N. Haque ${ }^{2}$ \& N. Ahmad ${ }^{1 \#}$ \\ ${ }^{1}$ Department of Livestock Production, University of Veterinary and Animal Sciences, Lahore 54000, Pakistan \\ ${ }^{2}$ Department of Animal Nutrition, University of Veterinary and Animal Sciences, Lahore 54000, Pakistan
}

(Received 31 January 2019; Accepted 26 July 2019; First published online 1 October 2019)

\author{
Copyright resides with the authors in terms of the Creative Commons Attribution 4.0 South African License. \\ See: http://creativecommons.org/licenses/by/4.0/za \\ Condition of use: The user may copy, distribute, transmit and adapt the work, but must recognize the authors and the South African \\ Journal of Animal Science.
}

\begin{abstract}
The objective of the present study was to investigate the effect of feeding rumen bypass fat on the growth of male Beetal goats. Twenty-seven male kids with an average bodyweight of $34 \pm 1.8 \mathrm{~kg}$ (mean \pm $\mathrm{SD}$ ) and aged 12 to 15 months were randomly divided into three treatment groups under a completely randomized design. The treatments consisted of : i) CON, basal diet without added fat (basal diet of chopped sorghum with $0.75 \mathrm{~kg}$ concentrate per animal); ii) MF, basal diet with added fat at $2.5 \%$ of dry matter in concentrate (Energizer-RP10, Scothorn Nutrition, Malaysia); and iii) HF, basal diet with added fat at 5\% of dry matter in concentrate. Dry matter intake (DMI) and faecal score were recorded daily. Live bodyweight was recorded fortnightly. Linear body measurements, which included wither height (WH), heart girth (HG), body length (BL), and body condition scores (BCS), were recorded monthly. The results indicated that the addition of bypass fat in concentrate did not affect DMI linearly. However, a quadratic trend of DMI was observed in response to fat addition $(P<0.1)$. The average daily gain was similar for CON, MF, and $\mathrm{HF}$ treatment groups $(P>0.05)$. Moreover, the addition of bypass fat did not affect the BCS, WH, HG, and BL. The HF group had a higher faecal score than the CON and MF groups $(P<0.05)$. The current findings conclude that the addition of bypass fat in diets did not improve the growth performance of yearling Beetal male goats.
\end{abstract}

Keywords: average daily gain, body measurements, supplemental fat

"Corresponding author: nisarahmad@uvas.edu.pk

\section{Introduction}

Pakistan ranks third in the world in goat numbers (FAOSTAT, 2019), but has limited feed resources for ruminant livestock, with $19 \%, 37 \%$, and $38 \%$ shortfalls of dry matter, protein, and energy, respectively (Habib et al., 2016). In these circumstances, most of the growing goats in field conditions are underfed. Providing these animals with an energy-rich diet for feedlot fattening could improve meat production.

The energy density of the daily ration can be improved by adding cereal grains, but the risk of subclinical rumen acidosis may limit the inclusion levels (Sutton et al., 2003). An alternative strategy to lower that risk could be the use of rumen bypass fat in the ration (Kumar, 2017). In addition to preventing ruminal acidosis, rumen bypass fat facilitates the modification of subcutaneous and intracellular fat deposition in the meat of animals. Indirectly, it reduces methane production as a result of lower ruminal fermentation (Beauchemin et al., 2008). Haddad \& Younas (2004) reported that supplementation of ruminally protected fat did not increase growth rate in lambs. Bhatt et al. (2015) found that the addition of protected fat to the diet of Malpura lambs improved average daily gain linearly. The use of protected fat for weight gain has been researched extensively in lambs (Kott et al., 2003; Ivan et al., 2004) and beef cattle (Dukett et al., 2002; Beaulieu et al., 2002) However, relatively fewer studies have been done on the use of protected fat in growing male goats. The objective of this study was therefore to investigate the effects of adding bypass fat to the diet of fattening Beetal yearling males on nutrient intake, growth, feed efficiency, body measurements, and body condition score. 


\section{Materials and Methods}

The trial was carried at the goat research facility of the University of Veterinary and Animal Sciences, Pattoki, Pakistan, during the dry summer season from April to June 2017. Twenty-seven male kids with average bodyweight of $34 \pm 0.5 \mathrm{~kg}$ (mean $\pm \mathrm{SD}$ ) and aged 12 to 15 months were randomly divided into three treatment groups under a completely randomized design. The treatments consisted of: CON, basal diet without added fat (chopped sorghum with $0.75 \mathrm{~kg}$ concentrate per animal); MF, basal diet with added fat at $2.5 \%$ of dry matter in concentrate (Energizer-RP10, Scothorn Nutrition, Malaysia); and HF, basal diet with added fat at $5 \%$ of dry matter in concentrate. The fresh sorghum fodder was harvested at the vegetative stage and was offered individually along with concentrate. The chemical compositions of each concentrate are given in Table 1.

Table 1 Ingredients and nutrient composition of concentrate used in a control diet and two diets that were augmented with fat

\begin{tabular}{lccc}
\hline \multirow{2}{*}{ Ingredients } & \multicolumn{3}{c}{ Treatments $^{\mathrm{a}}$} \\
\cline { 2 - 4 } & $\mathrm{CON}$ & $\mathrm{MF}$ & $\mathrm{HF}$ \\
\hline & 26 & 26 & 26 \\
Soybean meal & 26 & 26 & 26 \\
Canola meal & 16 & 16 & 16 \\
Corn ground & 27 & 24.5 & 22 \\
Wheat bran & 3 & 3 & 3 \\
Cane molasses & 0 & 2.5 & 5 \\
Bypass fats & 1 & 1 & 1 \\
Sodium bicarbonate & 0.4 & 0.4 & 0.4 \\
Limestone ground & 0.3 & 0.3 & 0.3 \\
Mineral mixture & 0.3 & 0.3 & 0.3 \\
Salt NaCl & 100 & 100 & 100 \\
Total & & & 25.1 \\
Chemical composition, per kg DM & 25.9 & 25.6 & 8.5 \\
Crude protein, \% & 4.1 & 6.3 & 11.2 \\
Ether extract, \% & 10.5 & 10.9 & 8.7 \\
Metabolizable energy (ME), MJ/kg & 6.1 & 8.4 & \\
Ash, \% & & & \\
\hline
\end{tabular}

1) ${ }^{\mathrm{a}} \mathrm{CON}$ : basal diet without added fat (chopped sorghum with $0.75 \mathrm{~kg}$ concentrate per animal); 2) MF, basal diet with added bypass fat (Energizer-RP10尺, Scothorn Nutrition, Malaysia) at 2.5\% of dry matter; and 3) HF, basal diet with added bypass fat at $5 \%$ of dry matter

Green fodder and concentrate were offered in the morning at 0700 hours daily. Refusals were collected next morning to measure DMI. Feed samples of fodder and concentrate were collected weekly for proximate analysis. Every sample was dried at $55^{\circ} \mathrm{C}$ for 24 hours in a hot air oven. Dry matter (DM) and crude protein (CP) were calculated according to the guidelines of AOAC (1990). A muffle furnace was used to determine the ash contents of the ration by burning the samples at $650{ }^{\circ} \mathrm{C}$ for four hours. Live bodyweights were recorded on day 1 and subsequently taken fortnightly. Weights were recorded with an electronic weighing balance early in the morning before feeding. The WH was taken with a vertical measuring tape adjusted with cross bar and levellers. The HG and BL were recorded with a simple measuring tape. All body measurements were recorded monthly in centimetres and taken when an animal was standing squarely on a level surface. The BCS of individual animal was recorded monthly on a scale of 1-5 (BCS 1: emaciated; BCS2: thin; BCS 3: normal; BCS 4: fatty; BCS 5: obese) as an indicator of physical growth (Villaquiran et al., 2005). Faecal scoring was done on a scale from 1-5 (Faecal score: FS 1: faecal 
balls, FS 2: attached balls; FS 3: pasty; FS 4: loose; FS 5: watery) daily for each animal (Dalton, 2018). Feed efficiency was calculated at the end of the trial.

The data were subjected to ANOVA under CRD design using Mixed Procedure of SAS (SAS, 2017) The linear and quadratic trends were tested. Results were declared statistically significant at $P<0.05$ and trend at $P<0.1$.

\section{Results and Discussion}

The results of DMI showed a quadratic trend in response to treatments (Table 2). The daily DMI was higher in MF compared with CON and HF. The findings of the current study were in line with those of other studies in which it was reported that supplementation of ruminally protected fat at higher levels than $2.5 \%$ reduced the DMI (Marinova et al., 2001; Haddad \& Younis, 2004). The gut peptides released in response to higher fat levels had a negative impact on DMI (Nawaz \& Ali, 2016).

There was no significant effect of bypass fat on daily weight gain in the current experiment (Table 2) $(P>0.05)$. The daily weight gain was numerically higher only in MF group (122 g/d) compared with CON (118 $\mathrm{g} / \mathrm{d})$ and HF (117 g/d). In agreement with the current findings, Haddad \& Younis (2004) reported that 2.5\% supplementation of ruminally protected fat in lambs was numerically higher than the control group, but higher levels had no effect on daily weight gain. Similarly, Salinas et al. (2006) and Seabrook et al. (2011) reported that bypass fat had no effect on daily weight gain. Live weight gain was highly correlated with metabolizable energy (ME) intake (Al Jassim et al., 1996). In the current study, the addition of bypass fat did not cause differences in ME intake among the three treatment groups. This could explain the similar daily weight gain for male Beetal goats. Contrary to the current results, some studies showed positive effects of bypass fat on weight gain in lambs (Bhatt et al., 2018). The difference in results could be attributed to different levels of bypass fat (4\%). Additionally, the species difference (lambs as opposed to yearling male goats) could explain the difference in results. Sheep can handle the metabolism of higher fat levels in diet than the goats (Bas \& Morand-Fehr, 2000). At higher levels of bypass fat, DMI was reduced because high energy density supplied the required nutrients.

Table 2 Effect of various levels of bypass fat on average daily weight gain and daily dry matter intake in yearling male Beetal goats

\begin{tabular}{|c|c|c|c|c|c|c|c|}
\hline \multirow{2}{*}{ Variables } & \multicolumn{3}{|c|}{ Treatments $^{1}$} & \multirow{2}{*}{ SEM } & \multicolumn{3}{|c|}{$P$-value } \\
\hline & CON & MF & $\mathrm{HF}$ & & Treat & Linear & Quadratic \\
\hline Initial bodyweight, kg & 34.0 & 33.9 & 34.1 & - & - & & \\
\hline Final bodyweight, kg & 41.1 & 41.3 & 41.1 & - & - & & \\
\hline Total gain, $\mathrm{kg}$ & 7.1 & 7.3 & 7.0 & - & - & & \\
\hline Average daily gain, g/day & 118 & 122 & 117 & 7.505 & 0.880 & 0.892 & 0.591 \\
\hline Daily dry matter intake, $\mathrm{kg}$ & 1.33 & 1.35 & 1.31 & 0.012 & 0.198 & 0.488 & 0.097 \\
\hline
\end{tabular}

${ }^{1} \mathrm{CON}$ : basal diet without added fat (chopped sorghum with $0.75 \mathrm{~kg}$ concentrate per animal); MF, basal diet with added bypass fat (Energizer-RP10®, Scothorn Nutrition, Malaysia) at $2.5 \%$ of dry matter; and HF, basal diet with added bypass fat at $5 \%$ of dry matter

The body measurements $(\mathrm{WH}, \mathrm{BL}, \mathrm{HG})$ and BCS $(\mathrm{HG})$ were similar $(P>0.05)$ among the treatment groups (Table 3). Body measurements are important predictors of weight (Eyduran et al., 2017). No effect of bypass fat supplementation on body measurements in the current study was similar to some previous studies which reported that bypass fat had no effect on physical body measurement in calves (Vahora et al., 2012; Kumar \& Thakur 2007). Body condition score is one of the indicators that determine the weight gain and health status during routine management. Because fat did not improve bodyweight gain in the current study, this could explain the current finding for BCS in response to fat addition. Unlike the current results, Ghani et al. (2017) reported increased BCS in growing female kids. In their study, the higher fat group had higher protein levels and the animals were younger. The differences in results could be ascribed to feed quality, fat sources, breeds, and growing age. Furthermore, the present trial was conducted in the summer season in the subtropical region of Pakistan. The hot and humid conditions might have hindered the fat response. 
Table 3 Effect of feeding various inclusion levels of bypass fat on growth and body condition scoring in male Beetal goats

\begin{tabular}{|c|c|c|c|c|c|c|c|}
\hline \multirow{2}{*}{ Variables } & \multicolumn{3}{|c|}{ Treatments $^{1}$} & \multirow{2}{*}{ SEM } & \multicolumn{3}{|c|}{$P$-value } \\
\hline & CON & MF & $\mathrm{HF}$ & & Treat & Linear & Quadratic \\
\hline $\mathrm{BCS}^{2}$ gain & 0.81 & 0.90 & 0.75 & 0.072 & 0.333 & 0.591 & 0.17 \\
\hline Wither height, cm & 81.27 & 81.75 & 79.54 & 1.1894 & 0.3986 & 0.314 & 0.365 \\
\hline Body length, $\mathrm{cmL}$ & 75.92 & 78.74 & 75.4 & 1.1886 & 0.1233 & 0.761 & 0.045 \\
\hline Hearth girth, cm & 77.99 & 80.09 & 79.45 & 0.9867 & 0.3223 & 0.306 & 0.269 \\
\hline Faecal score & 1.38 & 1.33 & 1.43 & 0.0265 & 0.0453 & 0.225 & 0.028 \\
\hline
\end{tabular}

${ }^{1} \mathrm{CON}$ : basal diet without added fat (chopped sorghum with $0.75 \mathrm{~kg}$ concentrate per animal); MF, basal diet with added bypass fat (Energizer-RP10®, Scothorn Nutrition, Malaysia) at $2.5 \%$ of dry matter; and HF, basal diet with added bypass fat at $5 \%$ of dry matter

${ }^{2} \mathrm{BCS}$ : body condition score

The addition of fat increased faecal score significantly (Table 3) $(P<0.05)$. The MF group had lower faecal score (1.33) than the HF group (1.43). Higher faecal scores were undesirable as they indicated abnormal changes in the rumen and post-ruminal environment. The higher content of bypass fat might have disturbed the micelle formation in the small intestine, thereby changing the faecal consistency.

\section{Conclusion}

The addition of bypass fat at levels greater than $2.5 \%$ of concentrate in diet did not increase the growth of yearling Beetal male goats. The ME difference between the treatment groups may not be sufficient to generate significant growth response. There is a need to further explore the use of bypass fat in goats under heat stress.

\section{Authors' Contributions}

IM and NA designed the experiment. MQ and NH carried out the analysis. IM and NA drafted the manuscript. MQS assisted with data analysis. NH arranged scientific content. All authors contributed editorial suggestions and supported the final manuscript draft.

\section{Conflict of Interest Declaration}

The contributing authors of this research study certify that they have no conflicts of interest.

\section{References}

Al Jassim, R., Hassan, S. \& Al-Ani, A., 1996. Metabolizable energy requirements for maintenance and growth of Awassi lambs. Small Ruminant Res. 20(3), 239-245.

AOAC, 1990. Official methods of analysis. 15th edition. Association of Analytical Chemists, Arlington, Virginia, USA

Bas, P. \& Morand-Fehr, P., 2000. Effect of nutritional factors on fatty acid composition of lamb fat deposits. Livest. Prod. Sci. 64(1), 61-79.

Beauchemin, K.A. \& McGinn, S.M., 2008. Reducing methane in dairy and beef cattle operations: What is feasible? Prairie Soil Crop 1, 17-21.

Beaulieu, A., Drackley, J.K. \& Merchen, N.R., 2002. Concentrations of conjugated linoleic acid (cis-9, trans-11octadecadienoic acid) are not increased in tissue lipids of cattle fed a high-concentrate diet supplemented with soybean oil. J. Anim. Sci. 80(3), 847-861.

Bhatt, R., Sahoo, A., Karim, S. \& Gadekar, Y., 2018. Effects of Saccharomyces cerevisiae and rumen bypass-fat supplementation on growth, nutrient utilisation, rumen fermentation and carcass traits of lambs. Anim. Prod. Sci. 58(3), 530-538.

Bhatt, R., Sahoo, A., Shinde, A. \& Karim, S., 2015. Effect of calcium salt of fatty acids supplementation on performance of Malpura lambs. Anim. Prod. Sci. 55(9), 1123-1130.

Dalton, C., 2018. Reduce worms and dags. Available at: https://www.fernleaframs.co.nz/reduce-worms-dags/. Accessed 10 April 2018.

Duckett, S., Andrae, J. \& Owens, F., 2002. Effect of high-oil corn or added corn oil on ruminal biohydrogenation of fatty acids and conjugated linoleic acid formation in beef steers fed finishing diets. J. Anim. Sci. 80(12), 3353-3360. 
Eyduran, E., Zaborski, D., Waheed, A., Celik, S., Karadas, K. \& Grzesiak, W., 2017. Comparison of the predictive capabilities of several data mining algorithms and multiple linear regression in the prediction of body weight by means of body measurements in the indigenous Beetal goat of Pakistan. Pak. J. Zool. 49(1).

FAOSTAT, D., 2013. Food and Agriculture Organization of the United Nations. Statistical database.

Ghani, A., Shahudin, M., Zamri-Saad, M., Zuki, A., Wahid, H., Kasim, A., Salisi, M. \& Hassim, H.A., 2017. Enhancing the growth performance of replacement female breeder goats through modification of feeding program. Vet. World 10(6), 630.

Habib, G., Fatah Ullah, K., Javaid, S. \& Saleem, M., 2016. Assessment of feed supply and demand for livestock in Pakistan. J. Agric. Res. Technol. A 6, 191-202.

Haddad, S. \& Younis, H., 2004. The effect of adding ruminally protected fat in fattening diets on nutrient intake, digestibility and growth performance of Awassi lambs. Anim. Feed Sci. Technol. 113(1), 61-69.

Ivan, M., Mir, P., Mir, Z., Entz, T., He, M. \& McAllister, T., 2004. Effects of dietary sunflower seeds on rumen protozoa and growth of lambs. Br. J. Nutr. 92(2), 303-310.

Kott, R., Hatfield, P., Bergman, J., Flynn, C., Van Wagoner, H. \& Boles, J., 2003. Feedlot performance, carcass composition, and muscle and fat CLA concentrations of lambs fed diets supplemented with safflower seeds. Small Ruminant Res. 49(1), 11-17.

Kumar, M., 2017. By pass fat in animal feeding - A review. J. Entomol. Zool. Stud. 5(6), 2251-2255.

Kumar, B. \& Thakur, S., 2007. Effect of supplementing bypass fat on the performance of buffalo calves. Indian J. Anim. Nutr. 24(4), 233-236.

Marinova, P., Banskalieva, V., Alexandrov, S., Tzvetkova, V. \& Stanchev, H., 2001. Carcass composition and meat quality of kids fed sunflower oil supplemented diet. Small Ruminant Res. 42(3), 217-225.

Nawaz, H. \& Ali, M., 2016. Effect of supplemental fat on dry matter intake, nutrient digestibility, milk yield and milk composition of ruminants. Pak. J. Agric. Sci. 53(1).

Salinas, J., Ramirez, R., Domínguez, M., Reyes-Bernal, N., Trinidad-Larraga, N. \& Montano, M., 2006. Effect of calcium soaps of tallow on growth performance and carcass characteristics of Pelibuey lambs. Small Ruminant Res. 66(1), 135-139.

SAS Institute. (2017). Base SAS 9.4 procedures guide: Statistical procedures. SAS Institute.

Seabrook, J., Peel, R. \& Engle, T., 2011. The effects of replacing dietary carbohydrate with calcium salts of fatty acids on finishing lamb feedlot performance, blood metabolites, muscle fatty acid composition, and carcass characteristics. Small Ruminant Res. 95(2), 97-103.

Sutton, J., Dhanoa, M., Morant, S., France, J., Napper, D. \& Schuller, E., 2003. Rates of production of acetate, propionate, and butyrate in the rumen of lactating dairy cows given normal and low-roughage diets. J. Dairy Sci. 86(11), 3620-3633.

Vahora, S., Parnerkar, S. \& Kore, K., 2012. Effect of feeding bypass nutrients to growing buffalo heifers under field conditions. Livestock Research for Rural Development 24(2), 39.

Villaquiran, M., Gipson, T., Merkel, R., Goetsch, A. \& Sahlu, T., 2005. Body condition scores in goats. Langston University, Langston, OK. 